\title{
Diet composition of the Pharaoh Eagle Owl, Bubo ascalaphus (Strigiformes, Strigidae) in a Steppe region of Algeria
}

\author{
Naceur Benamor ${ }^{1, *}$, Toufik Guetouache ${ }^{2} \&$ Farid Bounaceur $^{3}$
}

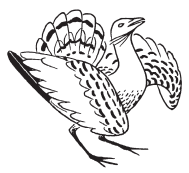

Received: August 30, 2021 - Revised: September 09, 2021 -Accepted: September 13, 2021

Benamor, N., Guetouache, T. \& Bounaceur, F. 2021. Diet composition of the Pharaoh Eagle Owl, Bubo ascalaphus (Strigiformes, Strigidae) in a Steppe region of Algeria. - Ornis Hungarica 29(2): 177-182. DOI: 10.2478/orhu-2021-0028

\begin{abstract}
The diet composition of Pharaoh Eagle Owl (Bubo ascalaphus) was investigated in a semiarid area of North-western Algeria. A total of 65 pellets regurgitated by the B. ascalaphus were analysed, 288 food items were composed primarily of mammal remains (4 rodents, 1 bat and insectivore, 93.7\%), and 1 bird species (passerine, $6.3 \%)$. The most frequent prey among the mammals were rodents (83.3\%), which included Mus musculus $(59.7 \%)$, Meriones shawi (11.1\%), Meriones libycus (11.1\%) and Jaculus jaculus (1.4\%). The rodents were the most important prey items in biomass $(91.4 \%)$, M. shawi made up to $41.9 \%$ of the total biomass. We may conclude that the Pharaoh Eagle Owl relies, in its feeding, very broadly on small mammals, completed by other groups.
\end{abstract}

Keywords: Pharaoh Eagle Owl, food habits, trophic ecology, Rechaïga area, Algerian steppe

Összefoglalás Az egyiptomi uhu (Bubo ascalaphus) táplálék összetételét vizsgáltuk Északnyugat-Algéria félszáraz területén. Összesen 65 köpetet elemeztünk és a 288 táplálékmaradvány alapján megállapítottuk, hogy a vizsgált területen a baglyok tápláléka elsősorban emlős maradványokból (4 rágcsáló, 1 denevér és rovarevő, 93,7\%) és 1 madárfaj (verébalakú, 6,3\%) maradványaiból álltak. Az emlösök közül leggyakrabban rágcsálókat (83,3\%) ejtettek el, mint a Mus musculus $(59,7 \%)$, Meriones shawi $(11,1 \%)$, Meriones libycus $(11,1 \%)$ és a Jaculus jaculus $(1,4 \%)$. A biomassza jelentős része is rágcsálókból $(91,4 \%)$ állt, a $M$. shawi a teljes biomassza 41,9\%-át tette ki. Ebből arra lehet következtetni, hogy az egyiptomi uhu táplálkozása nagyon széles körben támaszkodik a kisemlősökre, egyéb más fajokkal kiegészítve.

Kulcsszavak: egyiptomi uhu, táplálkozási szokások, trofikus ökológia, Rechaïga környéke, algériai sztyepp

${ }^{1}$ Department of Natural and Life Sciences, Ibn Khaldoun University, Tiaret, 14000, Algeria

${ }^{2}$ National Center of Biological Resources Development (CNDRB), Moudjebara Annex, Djelfa, 17058, Algeria

${ }^{3}$ Department of Natural and Life Sciences, Tissemsilt University, Tissemsilt, 38000, Algeria

* corresponding author, e-mail: naceur_mh28@yahoo.fr

\section{Introduction}

The Pharaoh Eagle Owl Bubo ascalaphus is largely distributed, its range extend from Northern Africa to the Middle East (Mohedano et al. 2014). This owl inhabits rocky mountain slopes in deserts and semi-deserts, but is found also in dry savannas, and locally endangered by human persecution, but its overall status is not known (Mikkola 2014).

The diet of the Pharaoh Eagle Owl is poorly known compared to its European counterpart, the Eurasian Eagle Owl Bubo bubo (Sándor \& Orbán 2008). It has long been speculated that the Pharaoh Eagle Owl and Eurasian Eagle Owl differ in ecology and behaviour (Sibley 
\& Monroe 1990). However, unlike its northern counterpart, little is known about the food habits of B. ascalaphus (Mohedano et al. 2014). Generally, this owl eats mammals, birds and reptiles, and also scorpions and larger insects (Mikkola 2014).

Previous diet studies of owls in Algeria have primarily focused on the following owl species: the Little Owl Athene noctua (Baziz et al. 2005, Sekour et al. 2010, 2011, Chenchouni 2014), the Tawny Owl Strix aluco (Hamdine et al. 1999), the Long-eared Owl Asio otus (Sekour et al. 2010), the Western Barn Owl Tyto alba (Baziz et al. 1999, Sekour et al. 2010) and the Short-eared Owl Asio flammeus (Djilali et al. 2012). Few studies have focused on the diet of Pharaoh Eagle Owl B. ascalaphus, especially in Algerian steppe environments (Sellami \& Belkacemi 1989, Boukhamza et al. 1994, Biche et al. 2001, Sekour et al. 2010) and listed small mammals, birds, reptiles and arthropods as prey. To better understand the basic ecological requirements of this species, we described its diet composition in a steppe region, North-western Algeria where no previous study has been carried out. We also provide an overview concerning the diet habits of B. ascalaphus.

\section{Materials and Methods}

The field study was conducted in Rechaïga area $\left(35^{\circ} 19^{\prime} \mathrm{N}, 02^{\circ} 06^{\prime} \mathrm{E}\right)$ located in Tiaret province, North-western Algeria, where the presence of the Pharaoh Eagle Owl is confirmed. The presence of nests and pellets were the main criteria for selecting the study area. The habitat located in the steppe region, which is characterised by a semiarid Mediterranean climate. The mean annual temperature is $17.1^{\circ} \mathrm{C}$, while the mean annual rainfall varies from 170 to $260 \mathrm{~mm}$. The vegetation is composed mainly of Pinus halepensis trees, part of the area is covered with shrubs, including Thymelaea hirsuta, Ziziphus lotus in association with Pistacia atlantica, and a few scattered tree individuals grow there. The forbs including Noaea mucronata, Peganum harmala, while grasses are e.g. Poa bulbosa, Hordeum murinum, Bromus rubens.

The diet composition of the Pharaoh Eagle Owl was studied based on pellets collected below the nests between June 2012 and March 2013. We determined remains of prey in the pellet samples by comparison of diagnostic body parts with material in private reference collections and information provided in works of Cuisin (1989) for bird species, and Bernard (1970), Barreau et al. (1991) and Aulagnier et al. (2009) for mammal species. We identified the prey items to the finest possible taxonomic category.

Diet composition was expressed as average relative numerical abundance $(N \%)$ for each prey item (Zaime \& Gautier 1989) and biomass (B\%) (Bayle 1996). In addition, to assess prey diversity in the diet, two measures were given: the Shannon-Weiner Diversity Index and Evenness ratio (Magurran 2004).

\section{Results}

A total of 65 pellets regurgitated by the Pharaoh Eagle Owl were analysed, 288 food items were composed primarily of mammal remains ( 4 rodents, 1 bat and insectivore, 93.7\%), and 
Table 1. Identified prey remains in Desert Eagle Owl pellets, Rechaïga area, North-western Algeria ni: Number of prey species; N\%: Average relative numerical abundance (\%); B\%: Biomass (\%).

1. táblázat Az egyiptomi uhu azonosított táplálékmaradványai Északnyugat-Algéria Rechaïga területéről

\begin{tabular}{|l|l|r|r|r|}
\hline \multicolumn{1}{|c|}{ Groups } & \multicolumn{1}{|c|}{ Prey species } & $\boldsymbol{n}_{\boldsymbol{i}}$ & $\mathbf{N} \%$ & $\mathbf{B \%}$ \\
\hline \multirow{4}{*}{ Rodents } & Mus musculus & 172 & 59.72 & 25.23 \\
\cline { 2 - 5 } & Meriones shawi & 32 & 11.11 & 41.86 \\
\cline { 2 - 5 } & Meriones libycus & 32 & 11.11 & 19.18 \\
\cline { 2 - 5 } & Jaculus jaculus & 4 & 1.39 & 5.17 \\
\hline Insectivores & Crocidura russula & 17 & 5.90 & 2.39 \\
\hline Bats & Pipistrellus sp. & 13 & 4.52 & 1.81 \\
\hline Mammals & & $\mathbf{2 7 0}$ & $\mathbf{9 3 . 7 5}$ & $\mathbf{9 5 . 6 4}$ \\
\hline Passeriformes & Passer sp. & 18 & 6.25 & 4.36 \\
\hline Birds & & $\mathbf{1 8}$ & $\mathbf{6 . 2 5}$ & $\mathbf{4 . 3 6}$ \\
\hline
\end{tabular}

1 bird species (passerine, 6.3\%) (Table 1). Most pellets (71\%) contained $\leq 3$ prey items; the rest contained 5-10 prey items. Out of the total 65 pellets, 46 contained only rodents, 12 contained remains of rodents, insectivores and birds. 7 pellets contained remains of a bats and/or insectivores.

The most frequent prey among the mammals were rodents $(83.3 \%)$, which included House Mouse Mus musculus (59.7\%), Shaw's Jird Meriones shawi (11.1\%), Libyan Jird Meriones libycus (11.1\%) and Lesser Egyptian Jerboa Jaculus jaculus (1.4\%) (Table 1). The bat Pipistrellus sp. and Greater White-toothed Shrew Crocidura russula, both constituted mammal prey with $5.9 \%$ and $4.5 \%$, respectively. The rodents were the most important prey items in biomass (91.4\%), M. shawi made up to $41.9 \%$ of the total biomass (Table 1). The $M$. musculus is the second most frequently recorded species (25.2\%), whilst all the remaining prey species together are below $9 \%$ of the total biomass. The diet diversity and evenness index of B. ascalaphus were 1.34 and 0.69 , respectively.

\section{Discussion}

The Pharaoh Eagle Owl's diet contained a wide variety of prey items that comprised mainly of small mammals (Abi-Said et al. 2020). With a diet that included $93.7 \%$ small mammals, our results corroborate those obtained by Denys et al. (1996), Boukhamza et al. (1994) and Biche et al. (2001) in Algeria, with 96\%, 95.4\% and 88.8\%, respectively. Moreover, the small mammals were the most preyed species $92 \%$ in Marrakech, Morocco (Barreau \& Bergier 2001a). Similar species of mammal rodents in the B. ascalaphus diet were found in the Mergueb Nature Reserve (Algeria) by Sekour et al. (2010). The Mus musculus, was the most preyed species support (Goodman 1990). The second species Meriones shawi, constituted a large proportion of biomass 41.9\% (Boukhamza et al. 1994, Sekour et al. 2010). Rodent remains were the main food species of $B$. ascalaphus, as well as, the presence of bat species, suggests that hunting for food was mostly done at night for species of greater 
biomass and energetic yield, yet, the presence of Meriones libycus, suggests crepuscular and/or diurnal hunting activity (Rifai et al. 2000, Abi-Said et al. 2020). The Greater Whitetoothed Shrew accounted for $5.9 \%$ of the total prey remains, and contributed only $2.4 \%$ in biomass, similarly to previous findings (Sekour et al. 2010, Chenchouni 2014), this species has been reported with low proportions in the Little Owl diet. Birds are not frequently preyed by Pharaoh Eagle Owls (Mohedano et al. 2014). Our result is similar to that obtained by Biche et al. (2001), who reported that $6.4 \%$ of the total species were birds. In addition, insects were absent in the Pharaoh Eagle Owl diet (Denys et al. 1996), but constituted a very low proportion of the diet in each of the following studies: Rathgeber and Bayle (1997), Boukhamza et al. (1994) and Biche et al. (2001), with 1\%,3.5\% and 4.8, respectively.

Diet diversity was very low, compared to other studies performed in steppe regions (Sekour et al. 2010). Likewise, the evenness index was low for B. ascalaphus in Rechaïga area. Since diet diversity often increases under conditions of food resource shortages (Gullion 1966), B. ascalaphus probably not selected more diverse diet because they were not under dietary stress. We may conclude that the Pharaoh Eagle Owl relies, in its feeding, very broadly on small mammals, completed by other groups. Further studies are needed to elaborate the seasonal fluctuation of the diet of the Pharaoh Eagle Owl in steppe regions as a function of the relative numerical abundance of the prey species in the environment.

\section{Acknowledgements}

The authors declare that this study is in accordance with national legislation.

\section{References}

Abi-Said, M. R., Al Zein, M., Abu Baker, M. A. \& Amr, Z. S. 2020. Diet of the Desert Eagle Owl, Bubo ascalaphus, in Eastern Saudi Arabia. - Pakistan Journal of Zoology 52(3): 1169-1171. DOI: 10.17582/ journal.pjz/20190130180117

Aulagnier, S., Haffner, P., Mitchell-Jones, A. J., Moutou, F. \& Zima, J. 2009. Mammals of Europe, North Africa and the Middle East. - A \& C Black Publishers, London

Barreau, D., Roche, A. \& Aulagnier, S. 1991. Eléments d'identification des crânes des rongeurs du Maroc [Identification elements of Rodent skulls from Morocco]. - Société Française Pour l'Étude et la Protection des Mammifères, Puceul (in French)

Barreau, D. \& Bergier, P. 2001a L'avifaune de la région de Marrakech (Haouz et Hauts Atlas de Marrakech, Maroc) 2. Les espèces non passereaux [The avifauna of the Marrakech region (Haouz and High Atlas, Morocco). 2 non-passerine]. - Alauda 69(1): 167-202. (in French with English Summary)

Bayle, P. 1996. Régime alimentaire du grand-duc d'Europe Bubo bubo en période de reproduction dans le Parc National du Mercantour et ses environs (Alpes-Maritimes et Alpes-de-Haute-Provence, France) [Diet of the Eurasian Eagle Owl Bubo bubo during the breeding season in Mercantour National Park and its surroundings (Alpes-Maritimes and Alpes-de-Haute-Provence, France)]. - Avocetta 20: 12-25. (in French with English Summary)

Baziz, B., Doumandji, S. \& Hamani, A. 1999. Adaptations trophiques de la Chouette effraie Tyto alba (Aves, Tytonidae) dans divers milieux en Algérie [Trophic adaptations of the Barn Owl Tyto alba (Aves, Tytonidae) in various environments in Algeria]. - Proceedings of the XXV ${ }^{\text {th }}$ International Congress of the International Union of Game Biologists, Greece, pp. 217-227. (in French with English Summary) 
Baziz, B., Sekour, M., Doumandji, S., Denys, C., Metref, S., Benjdabellah, S. \& Nadji, F. Z. 2005. Données sur le régime alimentaire de la Chouette chevêche Athene noctua en Algérie [Data on the diet of the Little Owl Athene noctua in Algeria]. - Aves 42: 149-157. (in French with English Summary)

Bernard, J. 1970. Clef de détermination des Rongeurs de Tunisie [Key to determination of Rodents from Tunisia]. - Archives de l'Institut Pasteur de Tunis 47: 265-307. (in French)

Biche, M., Sellami, M., Libois, R. \& Yahiaoui, N. 2001. Régime alimentaire du Grand-duc du désert, Bubo ascalaphus dans la réserve naturelle de Mergueb (M'Sila, Algérie) [Diet of the Pharaoh Eagle-owl Bubo ascalaphus in the Mergueb Nature Reserve (M'Sila, Algeria)]. - Alauda 69(4): 554-557. (in French with English Summary)

Boukhamza, M., Hamdine, W. \& Thevenot, M. 1994. Données sur le régime alimentaire du Grand-duc ascalaphe Bubo bubo ascalaphus en milieu steppique (Aïn Ouessera, Algérie) [Data on the diet of the Eagle Owl Bubo bubo ascalaphus in Steppic Environment (Aïn Ouessera, Algeria)]. - Alauda 62(2): 150 152. (in French with English Summary)

Chenchouni, H. 2014. Diet of the Little Owl (Athene noctua) during the pre-reproductive period in a semiarid Mediterranean region. - Zoology and Ecology 24(4): 314-323. DOI: 10.1080/21658005.2014.965919

Cuisin, J. 1989. L'identification des Cranes des Passereaux (Passeriformes: Aves) [Identification of Passerine Skulls (Passeriformes: Aves)]. - Bourgogne University, Bourgogne, Dijon (in French)

Denys, C., Dauphin, Y., Rzebik-Kowalski, B. \& Kowalska, K. 1996. Taphonomic study of Algerian owl pellet assemblages and differential preservation of some rodents: palaentological implications. - Acta Zoologica Cracoviensia 39(1): 103-116.

Djilali, K., Sekour, M. \& Bissati, S. 2012. Etude du régime alimentaire du hibou des marais, Asio flammeus (Pontoppidan, 1763) dans la région d'El-Golea [Study of the diet of Short-eared Owl, Asio flammeus (Pontoppidan, 1763) in the Region of El-Golea]. - Revue des Bioressources 2: 29-36. (in French with English Summary)

Goodman, S. M. 1990. The food habits of the Eagle Owl (Bubo bubo ascalaphus) in Kharga Oasis, Egyptian Western Desert. - Journal of Arid Environments 18: 217-220. DOI: 10.1016/s0140-1963(18)30855-3

Gullion, G. W. 1966. A viewpoint concerning the significance of studies of game bird habits. - Condor 68: 372 376. DOI: $10.2307 / 1365451$

Hamdine, W., Bouhhemza, M., Doumandji, S. E., Poitevin, F. \& Thévenot, M. 1999. Premières données sur le régime alimentaire de la Chouette hulotte (Strix aluco mauritanica) en Algérie [First Data on the diet of Tawny Owl (Strix aluco mauritanica) in Algeria]. - Ecologia Mediterranea 25: 111-123. (in French with English Summary)

Magurran, A. E. 2004. Measuring Biological Diversity. - Blackwell Publishing, Oxford

Mikkola, H., 2014. Owls of the World: A Photographic Guide. $2^{\text {nd }}$ ed. - Firefly Books, Richmond Hill, Ontario

Mohedano, I., Abu Baker, M. A., Hunter, B., Buchan, J., Michaels, C. J. \& Yamaguchi, N. 2014. On the diet of the Pharaoh Eagle Owl, Bubo ascalaphus (Savigny, 1809), in Qatar, with an overview of its feeding habits. - Zoology in the Middle East 60(2): 111-119. DOI: 10.1080/09397140.2014.914713

Rathgeber, C. \& Bayle, P. 1997. Régime alimentaire du Grand-duc d'Europe Bubo bubo, en période de reproduction, dans la région de Menton (Alpes-Maritimes, France) [Diet of the Eurasian Eagle Owl Bubo bubo, during the breeding season, in menton region (Alpes-Maritimes, France)]. - Alauda 65(4): 351-356. (in French with English Summary)

Rifai, L. B., Al-Melhim, W. N., Gharaibeh, B. M. \& Amr, Z. S. 2000. The diet of the Desert Eagle Owl, Bubo bubo ascalaphus, in the Eastern Desert of Jordan. - Journal of Arid Environments 44: 369-372. DOI: 10.1006/jare.1999.0601

Sándor, D. A. \& Orbán, Z. 2008. Food of the Desert Eagle Owl (Bubo ascalaphus) in Siwa Oasis, Western Desert, Egypt. - Zoology in the Middle East 44: 107-110. DOI: 10.1080/09397140.2008.10638295

Sekour, M., Baziz, B., Denys, C., Doumandji, S., Souttou, K. \& Guezoul, O. 2010. Régime alimentaire de la chevêche d'Athéna Athene noctua, de l'effraie des clochers Tyto alba, du hibou moyen-duc Asio otus et du grand-duc ascalaphe Bubo ascalaphus: Réserve naturelle de Mergueb (Algérie) [Diet of the Little Owl Athene noctua, the Barn Owl Tyto alba, the Long-eared Owl Asio otus and the Pharaoh Eagle Owl Bubo ascalaphus: Mergueb Nature Reserve (Algeria)]. - Alauda 78(2): 103-117. (in French with English Summary)

Sekour, M., Beddiaf, R., Souttou, K., Denys, C., Doumandji, S. E. \& Guezoul, O. 2011. Variation saisonnière du régime alimentaire de la chouette chevêche (Athene noctua) (Scopoli, 1769) dans l'extrême sud-est du Sahara algérien (Djanet, Algérie) [Seasonal Variation in the diet of the Little Owl (Athene noctua) (Scopoli, 
1769) in the Extreme Southeast of the Algerian Sahara (Djanet, Algeria)]. - Revue d'Ecologie (Terre et Vie) 66: 79-91. (in French with English Summary)

Sellami, M. \& Belkacemi, H. 1989. Le régime alimentaire du Hibou grand-duc Bubo bubo dans une réserve naturelle d'Algérie: le Mergueb [The diet of the Eagle Owl Bubo bubo in a Nature Reserve in Algeria: The Mergueb]. - L'Oiseau et la Revue Française d'Ornithologie 59: 329-332. (in French with English Summary)

Sibley, C. G. \& Monroe, B. L. 1990. Distribution and taxonomy of birds in the world. - Yale University Press, New Haven \& London

Zaime, A. \& Gautier, J. Y. 1989. Comparaison des régimes alimentaires de trois espèces sympatriques de Gerbillidae en milieu saharien au Maroc [Comparison of the diets of three sympatric species of Gerbillidae in the Saharan environment in Morocco]. - Revue d'Ecologie (Terre et Vie) 44(2): 153-163. (in French with English Summary)

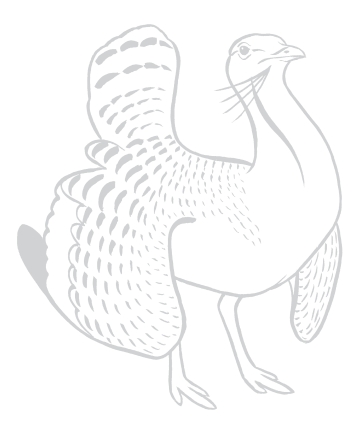

